Jurnal Ekonomi dan Industri

e-ISSN : 2656-3169

Volume 20, No. 3, September-Desember 2019

p-ISSN : 0853-5248

\title{
PENGARUH DISIPLIN KERJA DAN KOMPENSASI TERHADAP KINERJA KARYAWAN PT. TRI PUTRA MANDIRI
}

\author{
Lilis Muchlisa 1) \\ 1) Mahasiswa Program Studi Manajemen UNKRIS \\ Nuridin ${ }^{2)}$ \\ $\left.{ }^{2}\right)$ Dosen Program Studi Manajemen UNKRIS \\ Alamat: Kampus UNKRIS, Jatiwaringin Jakarta Timur \\ Email : h.nuridin58@gmail.com
}

\begin{abstract}
This study aims to analyze the effect of work discipline and compensation on the performance of employees of PT. Tri Putra Mandiri. This study uses 2 independent variables, namely work discipline and compensation for employee performance. This research uses census method with 35 respondents. The analytical method used is multiple linear regression and simple. Based on the analysis of statistical data, the indicators in this study are valid and reliable. In testing classic assumptions, the regression model is problem-free multicollinearity, does not occur heteroscedasticity, and is normally distributed. The results showed that the work discipline variable had a positive and significant effect on employee performance, and the compensation variable had a positive and significant effect on employee performance. This research is expected to bring benefits to companies, and for academia and for future researchers to be developed by looking at other variables.
\end{abstract}

Keywords: Work discipline, compensation, employee performance

\section{PENDAHULUAN}

Unsur utama dalam kemajuan perusahaan adalah sumber daya manusia, sebagai motor penggerak, insipirasi dan juga sebagai otak berjalannya suatu perusahaan, sumber daya manusia memberikan pengaruh yang sangat besar. Semakin baik yang dimiliki oleh perusahaan maka akan semakin baik kinerja dari perusahaan itu sendiri, sebaliknya, semakin rendah kualitas mutu sumber daya manusia yang dimiliki oleh perusahaan akan menjadi kinerja perusahaan menurun dan pada akhirnya akan mengekibatkan perusahaan hancur. Pada hakikatnya sumber daya manusia merupakan faktor terpenting sebagai penggeark dalam pelaksanaan seluruh kegiatan perusahaan didasarkan pada kemampuan serta kreatifitas yang dimilikinya sebagai kebutuhan untuk mencapai tujuan perusahaan. Berhasil tidaknya suatu perusahaan biasanya akan diketahui dari kemampuan perusahaan dalam mengelola sumber daya manusia yang dimiliki. Tujuan perusahaan akan tercapai tidak hanya tergantung pada peralatan serta sarana maupun prasarana yang lengkap, tetapi lebih utama adalah faktor manusia tersebut dalam mencapai tujuan perusahaan. Setiap karyawan yang memiliki kinerja yang tinggi dan baik akan memberikan kontribusi yang besar dalam mencapai tujuan dan sasaran-sasaran yang tleh ditetapkan oleh perusahaan.

Kinerja yang tinggi dapat dibentuk dengan adanya kesadaran setiap pimpinan perusahaan untuk memberikan dukungan kepada para karyawan berupa seberapa besar pimpinan perusahaan memberikan dukungan dan motivasi kepada karyawan dengan keikutertan pimpinan dalam mendukung pekerjaan yang dilakukan oleh karyawan, dengan demikian karyawan akan dapat memahami tentang tanggung jawab pekerjaan yang mereka kerjakan. Banyak faktor yang perlu diperhatikan dalam meningkatkan kinerja, antara lain 
lingkungan kerja yang nyaman, pemberian motivasi, penciptaan disiplin kerja yang baik dan kompensasi yang sesuai kepada setiap karyawan, hal ini tentunya akan dapat meningkatkan semangat kerja karyawan dalam bekerja. Mathis dan Jackson, (2006), mengemukakan kinerja pada dasarnya adalah "hasil kerja yang dicapai oleh seorang atau sekelompok orang dalam suatu perusahaan atau organisasi,sesuai dengan wewenang dan tanggung jawab masing-masing dalam rangka upaya mencapai tujuan perusahaan atau organisasi yang bersangkutan, secara legal tidak melanggar hukum dan sesuai dengan moral maupun etika".

Faktor yang pantas diperhatikan adalah disiplin kerja yang tinggi dan juga kompensasi yang diterima oleh karyawan yang bersangkutan. Selain itu, kepada karyawan diberikan rangsangan yang layak, semangat kerja karyawan dapat menjadi jelek apabila lingkungan kerjanya diabaikan. Sebab, lingkungan kerja karyawan selalu harus baik dan kondusif agar karyawan mempunyai tingkat semangat kerja yang tinggi didalam melaksanakan tugas-tugasnya. Karena apabila lingkungan kerja karyawan tidak baik dan tidak kondusif, maka semangat kerja karyawan akan menurun yang akhirnya mengakibatkan menurunnya kinerja kerja karyawan di dalam mencapai tujuan orgaisasi secara efektif dan efisien.

Kedisiplinan karyawan merupakan sikap penuh kerelaan dalam mematuhi semua aturan dan norma yang ada dalam menjalankan tugasnya sebagai bentuk tanggung jawabnya terhadap pekerjaannya. Kedisiplinan menurut Hasibuan, (2013) adalah "kesadaran dan kesediaan seseorang mentaati semua peraturan perusahaan, badan atau organisasi dan norma-norma sosial yang berlaku". Adanya tingkat disiplin kerja yang baik mencerminkan kredibilitas karyawan mancapai suatu hasil kerja yang optimal untuk kesuksesan perusahaan.

Kemudian dalam pelaksanaan disiplin kerja yang terjadi di PT. Tri Putr Mandiri, saat ini masih kurang optimal dan ini dapat dilihat dari beberpa hal antara lian: 1). Adanya karyawan yang mangkir kerja dengan berbagai alas an. 2). Adanya karyawan yang berkeliaran pada saat jam kerja. 3). ingkat kehadiran karyawan masih ada yang terlambat.

Tabel 1

Data Absensi Karyawan Tahun 2018

\begin{tabular}{lccccc}
\hline \multirow{2}{*}{ Bulan } & Jumlah & \multicolumn{3}{c}{ Absen } & \multirow{2}{*}{ Terlambat } \\
\cline { 3 - 5 } Karyawan & Sakit & Izin & Alfa & \\
\hline Januari & 35 & 3 & 1 & & 11 \\
Pebruari & 35 & 2 & 2 & 1 & 7 \\
Maret & 35 & 1 & 3 & & 6 \\
April & 35 & 4 & 1 & & 8 \\
Mei & 35 & 6 & 2 & & 4 \\
Juni & 35 & 3 & 1 & & 5 \\
Juli & 35 & 2 & 1 & 2 & 7 \\
Agustus & 35 & 5 & 3 & & 3 \\
September & 35 & 3 & 2 & & 4 \\
Oktober & 35 & 2 & 4 & & 6 \\
Nopember & 35 & 4 & 2 & & 4 \\
Desember & 35 & 2 & 4 & 1 & 3 \\
\hline
\end{tabular}

Sumber: PT Tri Putra Mandiri 2018

Disamping disiplin kerja peningkatan kinerja karyawan juga dapat dilaukan dengan cara pemberian kompensasi yang memadai bagi karyawan, kompensasi adalah imbalan 
yang diperoleh oleh karyawan berdasarkan prestasi, jawaban serta tanggung jawab yang dimilikinya. Semakin tinggi jabatan atau wewenang yang dimiliki maka akan semakin tinggi kompensasi yang diterimanya. Pada beberapa perusahaan, kompensasi tidak selalu berupa uang, ada yang memberikan berupa tunjangan perusahaan, tunjangan komunikasi bahkan ada yang perusahaan yang memberikan kompensasi kepada karyawan berupa liburan atau asuransi. Hasibuan (2013), menyampaikan kompensasi adalah "semua pendapatan yang berbentuk uang, barang langsung atau tidak langsung yang diterima karyawan sebagai imbalan atas jasa yang diberikan kepada perusahaan”. Program kompensasi mencerminkan usaha perusahaan untuk mempertahankan sumber daya manusia yang dimiliki. Pemberian kompenssi yang makin baik akan mendorong karyawan untuk bekerja dengan semakin baik dan produktif.

PT. Tri Putra Mandiri Didirikan pada tanggal 2 november 1993, sebagai perusahaan jasa trucking pengiriman barang. Sebagai perusahaan yang telah eksis lebih dari 25 tahun, kami selalu memberikan pelayanan yang terbaik untuk setiap customer kami, karena bagi kami menjaga kepercayaan dan hubungan yang baik dengan setiap customer adalah suatu kebanggaan tersendiri bagi perusahaan kami. Trucking adalah layanan jasa pengiriman barang via darat menggunakan armada mobil dan truck antar kota hingga antar pulau dimana barang yang akan dikirim dicampur bersama dengan milik orang lain untuk memenuhi kebutuhan pengiriman barang yang lebih murah dan cepat.

Sebagaimana yang kita ketahui, seiring dengan perkembangan jaman, trucking juga sering disebut dengan jasa cargo pengiriman via darat, dan banyak sekali bisnis angkutan darat, dan laut salah satunya adalah PT. Tri Putra Mandiri yg bergerak dibidang expedisi. Kegiatan ini mencangkup: penerimaan, penyimpanan, sortasi, pengepakan, penandaan, pengukuran, penimbangan, pengurusan penyelesesaian dokumen, penerbitan dokumen angkutan, perhitungan biaya angkutan, klaim, asuransi, atas pengiriman barang serta penyelesaian tagihan dan biaya-biaya lainnya berkenaan dengan pengiriman barang barang tersebut sampai dengan diterimanya barang oleh yang berhak menerimanya.

Proses pengiriman barang dengan jasa trucking memiliki banyak kelebihan dan manfaat yang lebih hemat dan efisien karena harga yang ditawarkan jauh lebih murah untuk barang - barang yang memiliki ukuran dan volume besar.

Menggunakan jasa trucking, pengiriman akan mendapatkan beberapa kelebihan berikut : a). Harga pengiriman barang yang lebih murah. b). Sanggup mengirim barang besar lebih dari $30 \mathrm{Kg}$. c). Menerima semua jenis barang kiriman. d). Mudah dipantau menggunakan sistem trucking. e). Pengiriman antar kota, ke luar pulau hingga ke luar negeri.

Tujuan penelitian ini adalah untuk mengetahui pengaruh disiplin kerja dan kompensasi terhadap kinerja karyawan PT. Tri Putra Mandiri.

\section{LANDASAN TEORI}

\section{Disiplin Kerja}

Disiplin merupakan sikap, tingkah laku dan perbuatan yang sesuai dengan peraturan perusahaan baik yang tertulis maupun yang tidak tertulis. Peraturan yang dimaksud termasuk absensi, lambat masuk, serta cepat pulang karyawan. Jadi hal ini merupakan suatu sikap indisipliner karyawan yang perlu disikapi dengan baik oleh pihak manajemen. Banyak yang mengartikan disiplin itu harus karyawan selalu datang serta pulang tepat pada waktunya. Pendapat itu hanya salah satu yang dituntut oleh organisasi. Oleh karena itu "kedisiplinan dapat diartikan sebagai tingkah laku yang tertulis maupun yang tidak tertulis". (Hasibuan, 2013). 
Menegakkan suatu kedisiplinan penting bagi perusahaan, sebab kedisiplinan berisikan peraturan-peraturan yang harus ditaati karyawan. Dengan kedisiplinan diharapkan dapat membuat pekerjaan seefisien mungkin. Disiplin kerja dapat dilihat sebagai sesuatu yang besar manfaatnya, baik bagi kepentingan organisasi maupun bagi para karyawan. Bagi organisasi adanya disiplin kerja akan menjamin terpeliharanya tata tertib dan kelancaran pelaksanaan tugas, sehingga diperoleh hasil yang optimal. Sedangkan bagi karyawan akan diperoleh suasana kerja yang menyenangkan sehingga akan menambah semangat kerja dalam melaksanakan pekerjaannya. Dengan demikian, karyawan dapat melaksanakan tugasnya dengan penuh kesadaran serta dapat mengembangkan tenaga dan pikirannya semaksimal mungkin demi terwujudnya tujuan perusahaan.

Kedisiplinan dalam suatu perusahaan dapat ditegakkan bilamana sebagian besar peraturan-peraturannya ditaati para anggota perusahaan tersebut. Gondokusumo, (1998), menyatakan Ada beberapa prilaku yang mudah menimbulkan persoalan atau pelanggaran peraturan disiplin antara lain: 1). "Terlalu banyak ngobrol dalam kerja. 2). Sikap terlalu santai atau masa bodoh. 3). Malas dan sedapat mungkin menghindari tugas 4). Suka campur tangan dalam kerja orang lain akan tetapi kerja sendiri tidak beres. 5). Tidak suka dengan tugas sekarang, selalu bosan, gaji terlalu kecil, tentang pangkat kenapa tidak dinaikkan. 6). Berlagak sangat sibuk padahal kerja yang dilakukan cuman sedikit. 7). Tidak tahu sesuatu yang harus dilakukan dengan berusaha menyelimuti hal ini karena malu. (terjadi antara karyawan baru dan yang lama). 8). Sangat peka, tidak mampu membalas cemooh rekan kerja, rasa kurang percaya diri memandang semuanya salah kecuali dirinya sendiri. 9). Syarat kerja dirasa terlalu menekan, tidak memberi kelonggaran untuk sebentarsebentar terlambat masuk atau sebentar-sebentar sakit. 10). Suka mengadu kepada pihak atasan, merasa hebat sekali karena pihak atasan meladeninya dan berlagak terhadap sesama kawan sekerja sehingga membangkitkan sesame mereka rasa benci dan juga takut".

Moekijat (2010), menyatakan tujuan utama dari disiplin adalah "untuk mendorong karyawan berprilaku sepantasnya ditempat kerja, dimana prilaku yang sepantasnya ditetapkan sebagai kepatuhan terhadap peraturan dan prosedur berfungsi sama dengan peraturan undang - undang masyarakat".

Disiplin kerja dapat dilihat sebagai sesuatu yang besar manfaatnya, baik bagi kepentingan organisasi maupun bagi para karyawan. Bagi perusahaan adanya disiplin kerja akan menjamin terpeliharanya tata tertib dan kelancaran pelaksanaan tugas, sehingga diperoleh hasil yang optimal. Sedangkan bagi karyawan akan diperoleh suasana kerja yang menyenangkan sehingga akan menambah semangat kerja dalam melaksanakan pekerjaannya. Dengan demikian, karyawan dapat melaksanakan tugasnya dengan penuh kesadaran serta dapat mengembangkan tenaga dan pikirannya semaksimal mungkin demi terwujudnya tujuan perusahaan.

Saydam (2006), menyebutkan manfaat dari penerapan disiplin kerja yang akan terlihat pada : 1). "Tingginya rasa kepedulian karyawan terhadap pencapaian tujuan perusahaan. 2). Tingginya semangat dan gairah kerja para karyawan dalam melakukan pekerjaannya. 3). Berkembangnya rasa memiliki dan kesetiakawanan yang tinggi di kalangan karyawan. 4). Besarnya tanggung jawab para karyawan melaksanakan tugas dengan sebaik-baiknya. 5). Meningkatnya efisiensi dan produktivitas para karyawan.

Pada dasarnya banyak indikator yang mempengaruhi tingkat kedisiplinan karyawan suatu perusahaan, diantaranya yang disampaikan oleh Moenir (2014). Indikator-indikator yang mempengaruhi disiplin kerja : 1). "Ketepatan waktu. Ketepatan waktu dalam pekerjaan dan tugas, meliputi : a). Ketepatan waktu dalam melaksanakan tugas. b). Penghematan waktu dalam melaksanakan tugas. 2). Tanggungjawab. Tanggungjawab 
dalam pekerjaan dan tugas, meliputi : a). Melakukan pekerjaan sesuai dengan rencana. b). Mengevaluasi hasil pekerjaan. c). Keberanian menerima resiko kesalahan. 3). Ketaatan. Ketaatan terhadap peraturan yang telah ditetapkan, meliputi : a). Ketaatan terhadap jam kerja. b). Ketaatan terhadap pimpinan. c). Ketaatan terhadap prosedur dan metode kerja".

\section{Kompensasi}

Kompensasi atau balas jasa adalah merupakan salah satu faktor yang sangat penting bagi kepentingan pekerjaan maupun untuk kepentingan perusahaan atau organisasi. Kompensasi bagi organisasi perusahaan adalah "merupakan unsur pembiayaan, dilain pihak bagi pekerja kompensasi merupakan sumber penghidupan ekonomi, disamping kompensasi juga merupakan penentu status sosial didalam masyarakat. Kompensasi semua bentuk bayaran atau hadiah bagi karyawan dan berasal dari pekerjaan mereka". (Dessler, 2015), sedangkan Wibowo (2010), mengemukakan "kompensasi merupakan kontra prestasi terhadap penggunaan tenaga atau jasa yang telah diberikan oleh tenaga kerja". Kompensasi merupakan jumlah paket yang ditawarkan oleh organisasi kepada pekerja sebagai imbalan atas penggunaan tenaga kerjanya.

Kompensasi merupakan sesuatu yang diterima karyawan sebagai pengganti kontribusi jasa mereka pada perusahaan. Pemberian kompensasi merupakan salah satu pelaksana fungsi manajemen sumber daya manusia yang berhubungan dengan semua jenis pemberian penghargaan individual sebagai pertukaran dalam melakukan tugas keorganisasian.

Proses kompensasi merupakan suatu jaringan yang kompel dengan maksud untuk memberikan balas jasa kepada karyawan bagi pelaksanaan pekerjaan dan untuk memotivasi mereka agar mencapai tingkat prestasi kerja yang diinginkan. Bagi manajemen, kompensasi karyawan mungkin merupakan masalah yang membingungkan dan sulit. Walaupun pengupahan harus mempunyai dasar yang logis dan dapat dipertahankan, hal ini banyak menyangkut faktor-faktor emosional dan sudut pandang karyawan. Namun dalam prakteknya, masalah kompensasi selalu saja menjadi acuan yang dapat mempengaruhi kinerja karyawan. Oleh karena itu, mau atau tidak mau organisasi juga perlu menganalisis kembali kebijakan-kebijakan yang diterapkan dalam hal pemberian kompensasi. Hal ini semata- mata guna menciptakan kinerja karyawan yang lebih baik, yang pada akhirnya menjadi kunci keberhasilan organisasi dalam mencapai tujuan yang telah ditetapkan sebelumnya.

Seseorang mau bekerja karena adanya sesuatu yang hendak dicapainya dan orang berharap bahwa aktivitas kerja yang dilakukannya membawa kepada sesuatu keadaan yang lebih memuaskan daripada keadaan sebelumnya. (Anoraga, 2009). Dengan demikian dapat dikatakan bahwa pada diri manusia terdapat kebutuhan- kebutuhan yang pada saatnya nanti membentuk tujuan- tujuan yang hendak dicapai dan dipenuhinya. Demi mencapai tujuan itu, orang terdorong untuk melakukan suatu aktivitas yang disebut bekerja.

Mangkunegara (2013), menyebutkan faktor-faktor yang mempengaruhi kompensasi sebagai berikut : 1). "Faktor pemerintah. Peraturan pemerintah yang berhubungan dengan penentuan standar gaji mminimal, pajak penghasilan, penetapan harga bahan baku,biaya transportasi/ angkutan, inflasi maupun devaluasi sangat mempengaruhi perusahan dalam menentukan kebijakan kompensasi pegawai. 2). Penawaran Bersama Antara Perusahan dan Pegawai. Kebijakan dalam menentukan kompensasi dapat di pengaruhi pula pada saat terjadinya tawar menawar mengenai besarnya upah yang harus di berikan oleh perusahan kepada pegawainya. 3). Standard dan biaya hidup pegawai. Kebijakan kompensasi perlu mempertimbangkan standard dan biaya hidup minimal pegawai. Hal ini karena kebutuhan dasar pegawai haus terpnuhi. Dengan terpenuhinya kebutuhan dasar pegawai dan 
keluarganya, maka pegawai akan merasa aman. Terpenuhinya kebutuhan dasar dan rasa aman pegawai akan memungkinkan pegawai dapat bekerja dengan penuh motivasi untuk mencapai tujuan perusahaan. 4). Ukuran perbandingan upah. Kebijakan dalam menentukan kompensasi dipengaruhi pula oleh ukuran besar kecilnya perusahan, tingkat pendidikan pegawai, masas kerja pegawai. Artinya, perbandingan tingkat upah pegawai perlu memperhatikan tingkat pendidikan, masa kerja, dan ukuran perusahaan. 5). Permintaan dan persediaan. Dalam menentukan kebijakan kompensasi pegawai perlu mempertimbangkan tingkat persediaan dan permintaan pasar. Artinya kondisi pasar pada saat itu perlu di jadikan bahan pertimbangan dalam menentukan tingkat upah pegawai. 6). Kemampuan Membayar. Dalam menentukan kebijakan kompensasi pegawai perlu didasarkan pada kemampuan perusahaan dalam membayar upah pegawai. Artinya jangan sampai menentukan kebijakan kompensasi di luar batas kemampuan yang ada pada perusahaan".

Samsudin (2006) dalam Kadarisman (2012), tujuan pemberian kompensasi adalah: 1). "Pemenuhan kebutuhan ekonomi Karyawan menerima kompensasi berupa upah, gaji atau bentuk lainnya adalah untuk memenuhi kebutuhan hidupnya sehari-hari atau dengan kata lain, kebutuhan ekonominya. Dengan adanya kepastian menerima upah atau gaji tersebut secara periodik, berarti adanya jaminan "economi security" bagi dirinya dan keluarga yang menjadi tanggung jawabnya. 2). Meningkatkan produktivitas kerja Pemberian kompensasi yang makin baik akan mendorong karyawan bekerja secara produktif. 3). Memajukan organisasi atau perusahaan Semakin berani suatu organisasi memberikan kompensasi yang tinggi, semakin menunjukkan betapa makin suksesnya organisasi, sebab pemberian kompensasi yang tinggi hanya mungkin apabila pendapatan organisasi atau perusahaan yang digunakan untuk itu makin besar. 4). Menciptakan keseimbangan dan keahlian Ini berarti bahwa pemberian kompensasi berhubungan dengan persyaratan yang harus dipenuhi oleh karyawan pada jabatan sehingga tercipta keseimbangan antara input (syarat-syarat) dan output".

Indikator kompensasi yang di kemukakan oleh Umar (2011) adalah: 1). "Gaji. Imbalan yang di berikan oleh pemberi kerja kepada pegawai, yang penerimaannya bersifat rutin dan tetap setiap bulan walaupun tidak masuk kerja maka gaji akan tetap diterima secara penuh. 2). Insentif. Penghargaan atau ganjaran yang diberikan untuk memotivasi para pekerja agar produktivitas kerjanya tinggi, sifatnya tidak tetap atau sewaktu-waktu. 3). Bonus. Pembayaran sekaligus yang diberikan karena memenuhi sasaran kinerja. 4). Upah. Pembayaran yang diberikan kepada pegawai dengan lamanya jam kerja. 5). Premi. Premi adalah sesuatu yang diberikan sebagai hadiah atau derma atau sesuatu yang dibayarkan ekstra sebagai pendorong atau perancang atau sesuatu pembayaran tambahan di atas pembayaran normal. 6). Pengobatan. Pengobatan di dalam kompensasi adalah pemberian jasa dalam penanggulan resiko yang dikaitkan dengan kesehatan karyawan. 7). Asuransi. Asuransi merupakan penanggulangan risiko atas kerugian, kehilangan manfaat dan tanggung jawab hukum kepada pihak ketiga yang timbul dari peristiwa yang tidak pasti”.

\section{Kinerja}

Manajemen kinerja (performance management) menurut Mondy (2010) adalah "proses berorientasi tujuan yang diarahkan untuk memastikan bahwa proses-proses keorganisasian berada pada tempatnya untuk memaksimalkan produktifitas para karyawan, tim dan akhirnya organisasi”. Wibowo (2010) berpendapat manajemen kinerja adalah "manajemen tentang menciptakan hubungan dan memastikan komunikasi yang efektif, memfokuskan pada apa yang diperlukan oleh organisasi, manajer dan pekerja untuk berhasil dan memperoleh sukses". Menurut Mangkunegara (2013) kinerja adalah "hasil 
kerja secara kualitas dan kuantitas yang dicapai oleh seorang pegawai dalam melaksanakan tugasnya sesuai gengan tanggung jawab yang diberikan kepadanya”. Menurut Hasibuan (2013) kinerja merupakan "suatu hasil kerja yang dicapai seseorang dalam melaksanakan tugasnya atau kecakapan usaha dan kesempatan". Kinerja adalah "hasil kerja yang dicapai oleh seseorang atau kelompok orang dalam suatu organisasi, sesuai dengan wewenang dan tanggjung jawab masing-masing dalam rangka upaya mencapai tujuan organisasi bersangkutan, secara legal tidak melanggar hukum dan sesuai dengan moral maupun etika". (Mathis dan Jackson, 2006).

Berdasarkan paparan di atas kinerja adalah suatu hasil yang di capai seseorang dalam melaksanakan tugas - tugas yang didasarkan atas kecakapan, pengalaman dan kesungguhan serta waktu menurut standart dan kriteria yang telah ditetapkan sebelumnya. Jadi kinerja adalah suatu hasil yang dicapai seseorang dalam melaksanakan tugas - tugas yang didasarkan atas kecakapan, pengalaman, dan kesungguhan serta waktu menurut standar. Begitu pentingnya masalah kinerja karyawan ini sehingga tidak salah bila inti pengelolaan sumber daya manusia adalah bagaimana mengelola kinerja sumber daya manusia. Mengelola manusia dalam konteks organisasi berarti mengelola manusia agar dapat menghasilkan kinerja yang optimal bagi organisasi. Oleh karena itu, kinerja pegawai ini perlu dikelola secara baik untuk mencapai tujuan organisasi sehingga menjadi suatu konsep manajemen kinerja.

Faktor yang mempengaruhi kinerja karyawan menurut (Prawirosentono, 2002), yaitu: 1). "Efektifitas dan efisiensi. Bila suatu tujuan tertentu akhirnya bisa dicapai, kita boleh mengatakan bahwa kegiatan tersebut efektif tetapi apabila akibat-akibat yang tidak dicari kegiatan menilai yang penting dari hasil yang dicapai sehingga mengakibatkan kepuasan walaupun efektif dinamakan tidak efesien. Sebaliknya, bila akibat yang dicaricari tidak penting atau remeh maka kegiatan tersebut efesien. 2). Otoritas (wewenang). Otoritas menurut adalah sifat dari suatu komunikasi atau perintah dalam suatu organisasi formal yang dimiliki seorang anggota organisasi kepada anggota yang lain untuk melakukan suatu kegiatan kerja sesuai dengan kontribusinya. Perintah tersebut mengatakan apa yang boleh dilakukan dan yang tidak boleh dalam organisasi tersebut. 3). Disiplin. Disiplin adalah taat kepda hukum dan peraturan yang berlaku. Jadi, disiplin karyawan adalah kegiatan karyawan yang bersangkutan dalam menghormati perjanjian kerja dengan organisasi dimana dia bekerja. 4). Inisiatif. Inisiatif yaitu berkaitan dengan daya pikir dan kreatifitas dalam membentuk ide untuk merencanakan sesuatu yang berkaitan dengan tujuan organisasi”.

Robbins, et, al (2014), indikator untuk mengukur kinerja karyawan secara individu ada lima indikator : 1). "Kualitas. Kualitas kerja diukur dari persepsi karyawan terhadap kualitas pekerjaan yang dihasilkan serta kesempurnaan tugas terhadap keterampilan dan kemampuan karyawan. 2). Kuantitas. Merupakan jumlah yang dihasilkan dinyatakan dalam istilah seperti jumlah unit, jumlah siklus aktivitas yang diselesaikan. 3). Ketepatan waktu. Merupakan tingkat aktivitas diselesaikan pada awal waktu yang dinyatakan, dilihat dari sudut koordinasi dengan hasil output serta memaksimalkan waktu yang ada untuk aktifitas lain. 4). Efektifitas. Merupakan tingkat penggunaan sumber daya organisasi (tenaga, uang, teknologi, bahan baku) dimaksimalkan dengan maksud manaikkan hasil dari setiap unit dalam penggunaan sumber daya. 5). Kemandirian. Merupakan tingkat seorang karyawan yang nantinya akan menjalankan fungsi kerjanya komitmen kerja. Merupakan suatu tingkat dimana karyawan mempunyai komitmen kerja dengan instansi dan tanggung jawab karyawan terhadap perusahaan". 


\section{METODE PENELITIAN}

Metode Penelitian ini menggunakan penelitian kuantitatif dalam melihat pengaruh atau hubungan variabel terhadap objek yang diteliti lebih bersifat sebab akibat (kausal), sehingga dalam penelitiannya terdapat variabel independen dan variabel dependen. Dari variabel tersebut, selanjutnya dicari seberapa besar pengaruh variabel independen terhadap variabel dependen. (Sugiyono, 2016).

Populasi dalam penelitian ini adalah karyawan PT. Tri Putra Mandiri yang berjumlah 35 orang. Dalam penelitian ini, data yang digunakan adalah data kuantitatif dengan cara mengumpulkan data melalui kuisioner dan wawancara. Teknik Analisis Data dengan Uji validitas dan Uji reliabilitas, selanjutnya dilakukan model dengan menggunakan analisis regresi linear berganda dan sederhana.

\section{HASIL PENELITIAN DAN PEMBAHASAN}

\section{Uji Instrumen Data}

Berdasarkan uraian tersebut di atas, maka untuk dapat menentukan apakah variabel disiplin kerja dan kompensasi dapat dijadikan pengukur terhadap kinerja karyawan PT. Tri Putra Mandiri.

\section{Uji Validitas}

Pengujian validitas ini dilakukan untuk menguji apakah tiap butir pernyataan telah mewakili indikator yang akan diteliti, persyaratan minimum untuk dapat dikatakan valid adalah $r=0,30$. Jadi, apabila korelasi antara butir-butir item pernyataan dengan skor total kurang dari 0,30, maka butiran dalam instrumen tersebut dapat dikatakan tidak valid. Uji validitas dilakukan dengan melihat korelasi antara skor masing-masing item pernyataan dengan skor total.

\section{Uji Validitas Instrumen Variabel}

Dari perhitungan koefisien korelasi skor tiap butir pernyataan instrument disiplin kerja dari 35 responden, dengan jumlah 9 pernyataan; instrumen kompensasi 9 pernyataan dan instrumen kinerja karyawan 10 pernyataan dengan total skor setiap responden diperoleh hasil yang disajikan dalam tabel sebagai berikut:

Tabel 1 : Hasil Uji Validitas Instrumen Variabel

\begin{tabular}{cccccc}
\hline \multirow{2}{*}{ Pernyataan } & \multicolumn{4}{c}{ R Hitung } & Disiplin \\
\cline { 2 - 4 } & Kerja & Kompensasi & $\begin{array}{c}\text { Kinerja } \\
\text { Karyawan }\end{array}$ & R Kritis & Kesimpulan \\
\hline Butir. 1 & 0.649 & 0.404 & 0.610 & 0.300 & Valid \\
Butir. 2 & 0.695 & 0.641 & 0.579 & 0.300 & Valid \\
Butir. 3 & 0.643 & 0.680 & 0.700 & 0.300 & Valid \\
Butir. 4 & 0.630 & 0.683 & 0.655 & 0.300 & Valid \\
Butir. 5 & 0.700 & 0.765 & 0.678 & 0.300 & Valid \\
Butir. 6 & 0.732 & 0.642 & 0.572 & 0.300 & Valid \\
Butir. 7 & 0.663 & 0.721 & 0.625 & 0.300 & Valid \\
Butir. 8 & 0.622 & 0.678 & 0.569 & 0.300 & Valid \\
Butir. 9 & 0.684 & 0.726 & 0.607 & 0.300 & Valid \\
Butir. 10 & - & - & 0.445 & 0.300 & Valid \\
\hline
\end{tabular}

Sumber : Data primer, 2019 
Berdasarkan Tabel-1, dapat dilihat dan disimpulkan bahwa dari semua butir pernyataan variabel disiplin kerja, kompensasi dan kinerja karyawan hasilnya adalah valid.

\section{Uji Reliabilitas}

Pengujian reliabilitas ini dilakukan untuk menguji seberapa jauh hasil pengukuran yang dapat diandalkan secara konsisten. Pada Tabel-2, hasil pengujian reliabilitas berikut diketahui bahwa semua variabel mempunyai alpha di atas 0,6 yang berarti bahwa semua variabel dalam penelitian ini dapat diandalkan.

Tabel 2 : Hasil Uji Reliabilitas Variabel

\begin{tabular}{lcc}
\hline \multicolumn{1}{c}{ Variabel } & Cronbach's Alpha & Keterangan \\
\hline Disiplin Kerja & 0.843 & Reliabel \\
Kompensasi & 0.842 & Reliabel \\
Kinerja Karyawan & 0.802 & Reliabel \\
\hline
\end{tabular}

Sumber: Hasil pengolahan data, 2019

Berdasarkan Tabel-2, dapat dilihat dan disimpulkan bahwa nilai Cronbach's Alpha positif dimana lebih besar dari 0,6 yang merupakan batas minimal koefisien reliabilitas dapat dianggap baik. Dengan demikian, dikatakan bahwa pernyataan di atas reliabel.

\section{Pengujian Model}

Tabel 3: Pengaruh Disiplin Kerja dan Kompensasi Terhadap Kinerja Karyawan PT. Tri Putra Mandiri

\begin{tabular}{lcccccc}
\hline Hubungan & \multicolumn{7}{c}{ Parameter } \\
\cline { 2 - 6 } Variabel & Mult. R & R Square & Konstanta & Koef. B & Sig. & $\boldsymbol{\alpha}$ \\
\hline Disiplin Kerja & \multirow{2}{*}{0.865} & 0.749 & \multirow{2}{*}{12.196} & 0.380 & 0.003 & \multirow{2}{*}{0.05} \\
Kompensasi & & & & 0.121 & 0.001 & \\
\hline Pengujian Signifikansi & & & & \\
\hline
\end{tabular}

Keterangan : Variabel Kinerja Karyawan

Sumber: data diolah 2019

Berdasarkan Tabel-3, nilai $\mathrm{F}$ hitung $=47,631$ lebih besar dibandingkan dengan F tabel 3,295, maka dapat diartikan terdapat pengaruh signifikan disiplin kerja dan kompensasi terhadap kinerja karyawan PT. Tri Putra Mandiri.

Nilai R square adalah sebesar 0,749 atau 74,9\%. Hal ini berarti bahwa disiplin kerja dan kompensasi memberikan kontribusi kepada kinerja karyawan PT. Tri Putra Mandiri adalah sebesar $74.9 \%$, sedangkan sisanya sebesar $25.1 \%$ disumbangkan oleh variabel lainnya yang tidak diteliti.

Berdasarkan hasil perhitungan koefisien regresi diperoleh persamaan regresi yaitu sebesar $\mathrm{Y}=12,196+0,380\left(\mathrm{X}_{1}\right)+0,121\left(\mathrm{X}_{2}\right)$.

Koefisien disiplin kerja adalah sebesar 0,380. Hal ini berarti bahwa setiap peningkatan satu kali disiplin kerja, maka kinerja karyawan PT. Tri Putra Mandiri akan meningkat sebesar 0,380 kali, dengan asumsi kompensasi tetap. Koefisien kompensasi adalah sebesar 0,121 . Hal ini berarti bahwa setiap peningkatan satu kali kompensasi, maka kinerja karyawan PT. Tri Putra Mandiri akan meningkat sebesar 0,121 kali, dengan asumsi disiplin kerja tetap. 
Tabel 4: Pengaruh Disiplin Kerja Terhadap Kinerja Karyawan

PT. Tri Putra Mandiri

\begin{tabular}{lcccccc}
\hline Hubungan & \multicolumn{7}{c}{ Parameter } \\
\cline { 2 - 7 } Variabel & Mult. R & R Square & Konstanta & Koef. B & Sig. & $\boldsymbol{\alpha}$ \\
\hline Disiplin Kerja & 0.798 & 0.636 & 17.111 & 0.712 & 0.000 & 0.05 \\
\hline Pengujian Signifikansi & & & & & \\
\hline t hitung > t tabel $=7.599>2.035$ & & & & \\
\hline & $\begin{array}{l}\text { Keterangan : Variabel Kinerja Karyawan } \\
\text { Sumber: data diolah } 2019\end{array}$
\end{tabular}

Berdasarkan Tabel-4, nilai R square adalah sebesar 0,636 atau 63,6\%. Hal ini berarti bahwa disiplin kerja memberikan kontribusi kepada kinerja karyawan PT. Tri Putra Mandiri adalah sebesar $63,6 \%$, sedangkan sisanya sebesar 36,4\% disumbangkan oleh variabel lainnya yang tidak diteliti.

Berdasarkan hasil perhitungan koefisien regresi diperoleh persamaan regresi yaitu sebesar $\mathrm{Y}=17,111+0,712\left(\mathrm{X}_{1}\right)$.

Koefisien disiplin kerja adalah sebesar 0,712. Hal ini berarti bahwa setiap peningkatan satu kali disiplin kerja, maka kinerja karyawan PT. Tri Putra Mandiri akan meningkat sebesar 0,712 kali. Berdasarkan perhitungan tersebut tabel 4, dapat dinyatakan bahwa nilai t hitung = 7,599 lebih besar dibandingkan dengan t tabel 2,035, maka dapat diartikan terdapat pengaruh yang positif dan signifikan disiplin kerja terhadap kinerja karyawan PT. Tri Putra Mandiri.

Tabel 5: Pengaruh Kompensasi Kerja Terhadap Kinerja Karyawan PT. Tri Putra Mandiri

\begin{tabular}{ccccccc}
\hline Hubungan & \multicolumn{7}{c}{ Parameter } \\
\cline { 2 - 7 } Variabel & Mult. R & R Square & Konstanta & Koef. B & Sig. & $\boldsymbol{\alpha}$ \\
\hline Kompensasi & 0.817 & 0.667 & 14.958 & 0.748 & 0.000 & 0.5 \\
\hline Pengujian Signifikansi & & & & & \\
\hline t hitung $>$ t tabel $=8.133>2.035$ & & & \\
\hline
\end{tabular}

Keterangan : Variabel Kinerja Karyawan

Sumber: data diolah 2019

Berdasarkan Tabel-5, nilai R square adalah sebesar 0,667 atau 66,7\%. Hal ini berarti bahwa kompensasi memberikan kontribusi kepada kinerja karyawan PT. Tri Putra Mandiri adalah sebesar $66,7 \%$, sedangkan sisanya sebesar 33,3\% disumbangkan oleh variabel lainnya yang tidak diteliti, seperti disiplin kerja.

Berdasarkan hasil perhitungan koefisien regresi diperoleh persamaan regresi yaitu sebesar $\mathrm{Y}=14,958+0,748\left(\mathrm{X}_{2}\right)$.

Koefisien kompensasi adalah sebesar 0,748. Hal ini berarti bahwa setiap peningkatan satu kali kompensasi, maka kinerja karyawan PT. Tri Putra Mandiri akan meningkat sebesar 0,748 kali. Berdasarkan perhitungan tersebut tabel 5 dapat dinyatakan bahwa nilai $\mathrm{t}$ hitung $=11,085$ lebih besar dibandingkan dengan $\mathrm{t}$ tabel 1,998, maka dapat diartikan terdapat pengaruh yang signifikan disiplin kerja terhadap kinerja karyawan PT. Tri Putra Mandiri.

\section{Pembahasan}

Dari hasil penelitian menunjukan bahwa adanya peningkatan disiplin kerja mendorong akan dapat meningkatkan kinerja karyawan PT. Tri Putra Mandiri. Hal ini 
dikarenakan pernyataan bahwa karyawan tepat waktu dalam melaksanakan tugas, adanya penghematan waktu dalam bertugas, pekerjaan diselesaikan sesuai target, pekerjaan dikerjakan sesuai rencana, mengevaluasi hasil pekerjaan, berani mengambil risiko atas kesalahan, hadir sesuai dengan jam kerja, taat terhadap pimpinan dan mengikuti semua prosedur dan metode kerja. Hasil penelitian ini sejalan dengan hasil penelitian yang dilakukan Noel, et, al (2017) dan Wairooy, (2017) yang menyatakan bahwa disiplin kerja berpengaruh positif dan signifikan terhadap kinerja karyawan.

Dari hasil penelitian menyatakan bahwa adanya peningkatan kompensasi mendorong akan dapat meningkatkan kinerja karyawan PT. Tri Putra Mandiri. Hal ini dikarenakan pernyataan bahwa gaji diterima setiap bulan tepat waktu, gaji yang diterima dapat mencukupi kebutuhan setiap bulan, insentif diberikan kepada karywan yang produktif, besarnya bonus disesuaikan dengan kemampuan kerja karyawan, upah diberikan pada karyawan yang melebihi jam kerja, pemberian premi untuk mendorong prestasi kerja karyawan, perusahaan memberikan pengobatan terhadap kecelakaan kerja, karyawan diberikan jaminan asuransi dan keluarga karyawan diprotek asuransinya. Hasil penelitian ini sejalan dengan hasil penelitian yang dilakukan Satedjo, et, al (2017) dan Wardoyo, (2016) yang menyatakan bahwa kompensasi berpengaruh positif dan signifikan terhadap kinerja karyawan.

\section{KESIMPULAN DAN SARAN}

\section{Kesimpulan}

Setelah melakukan pembahasan, penulis akan mencoba menarik suatu kesimpulan yang dapat di sampaikan sebagai berikut: 1). Disiplin Kerja dan Kompensasi secara bersama-sama berpengaruh signifikan terhadap kinerja karyawan PT. Tri Putra Mandiri. 2). Disiplin Kerja berpengaruh positif dan signifikan terhadap kinerja karyawan PT. Tri Putra Mandiri. 3). Kompensasi berpengaruh positif dan signifikan terhadap kinerja karyawan PT. Tri Putra Mandiri.

\section{Saran}

Saran dan masukan yang dapat penulis berikan terhadap objek yang diteliti yaitu PT. Tri Putra Mandiri adalah sebagai berikut: 1). Disiplin Kerja karyawan relatif sudah baik, hampir semua aturan yang diterapkan dapat dipatuhi oleh para karyawan, walaupun masih ada satu atau dua orang karyawan yang kurang disiplinnya, dan untuk itu perusahaan terus meningkatkan disiplin kerja para karyawannya, hal ini perlu kiranya perusahaan memperhatikan keinginan dan keluhan yang terjadi pada karyawan, penting untuk diperhatikan agar mereka tetap menjaga disiplin kerja yang sudah ada. 2). Kompensasi yang diberikan perusahaan sudah memenuhi standar yang ditetapkan oleh perusahaan, namun demikian alangkah baiknya bila perusahaan dapat meningkatkan kompensasi dari yang sudah ada agar kinerja dari pada karyawan dapat lebih bersemangat dan menghasilkan produktivitas yang tinggi, sehingga perusahaan akan lebih berhasil dalam mencapai tujuan yang sudah ditetapkan. 3). Disiplin kerja dan kompensasi merupakan dua faktor yang saling berkaitan untuk dapat meningkatkan kinerja karyawan, pada PT. Tri Putra Mandiri, hal ini sudah berjalan dengan mengikuti aturan yang ditetapkan, tentunya ini dapat terus dipertahankan dan ditingkatkan. 4). Peneliti Selanjutnya: Bagi peneliti selanjutnya disarankan untuk menambah variabel-variabel lain yang lebih bervariasi dalam membahas yang berhubungan dengan kinerja karyawan. 


\section{DAFTAR PUSTAKA}

Anoraga, Pandji. 2009. Manajemen Bisnis. Jakarta : Penerbit PT. Rineka Cipta.

Dessler, Gary. 2015. Manajemen Sumber Daya Manusia (Human Resource Management), Edisi 14. Jakarta. Penerbit Salemba Empat.

Gondokusumo, A. A. 1998. Komunikasi Pengusaha. Jakarta: PT. Toko Gunung Agung.

Hasibuan, Malayu S. P. 2013. Manajemen Sumber Daya Manusia. Cetakan Kesembilan. Jakarta : Penerbit PT. Bumi Aksara.

Kadarisman,M.. 2012. Manajemen Pengembangan Sumber Daya Manusia. Jakarta: Penerbit Rajawali Pers.

Mangkunegara, Anwar Prabu. 2013. Manajemen Sumber Daya Manusia Perusahaan. Bandung. Penerbit Remaja Rosda Karya.

Mathis, Robert L dan Jhon H. Jackson. 2006. Manajemen Sumber Daya Manusia, Buku 2, Edisi 9 Penerjemah: Jimmy Sadeli dan Bayu Prawira Hie. Jakarta. Penerbit Salemba Empat.

Moekijat. 2010. Manajemen Sumber Daya Manusia. Cetakan Kesembilan. Bandung: Penerbit Mandar Maju

Moenir, H.A.S. 2014. Manajemen Pelayanan Umum di Indonesia. Jakarta: Bumi Aksara.

Mondy, R. Wayne. 2010. Manajemen Sumber Daya Manusia, Jilid 2, Edisi 10. Jakarta. Penerbit Erlangga.

Noel, Flavia Reva, Juyce Lapian dan Merinda Pandowo. 2017. "Pengaruh Disiplin Kerja dan Kompetensi Terhadap Kinerja Pegawai (Studi Kasus Balai Kesehatan Mata Masyarakat Sulawesi Utara)". Jurnal EMBA, Vol. 5, No. 3, Hal:3528-3537.

Prawirosentono, Suyadi. 2002. Manajemen Sumber Daya Manusia: Kebijakan Kinerja Karyawan. Edisi 1. Cetakan Kedelapan. Yogyakarta : Penerbit BPFE.

Robbins, Stephen P. \& Timothy A. Judge. 2014. Perilaku Organisasi, Edisi 16. Jakarta. Penerbit Salemba Empat.

Samsudin, Sadili. 2006. Manajemen Sumber Daya Manusia. Bandung: Penerbit Pustaka Setia

Satedjo, Ananta Dwikristianto dan Sesilya Kempa. 2017. "Pengaruh Kompensasi dan Disiplin Kerja Terhadap Kinerja Karyawan PT. Modern Widya Tehnical Cabang Jayapura". Jurnal AGORA, Vol. 5, No. 3.

Saydam, Gouzali. 2006. Manajemen Sumber Daya Manusia: Suatu Pendekatan Mikro. Jakarta: Penerbit Djambaran.

Sugiyono. 2016. Statikstika Untuk Penelitian. Bandung: Penerbit Alfabeta.

Umar, Husein. 2011. Riset Manajemen Sumber Daya Manusia dan Organisasi. Jakarta: Penerbit PT. Gramedia Pustaka Utama.

Wairooy, Ali. 2017. "Pengaruh Disiplin Kerja dan Kompensasi Terhadap Kinerja Karyawan Pada Pt. Pertamina (Persero), Tbk. Pemasaran Region VII Makassar". Jurnal Pemikiran Ilmiah dan Pendidikan Adminstrasi Perkantoran, Vol 4, No.1.

Wardoyo, Dewi Tri Wijayati. 2016., International Journal of Business and Management, Vol. 11 No. 1, 2016, p- ISSN: 1833-3850; e-ISSN: 1833-1819, "Pengaruh Disiplin dan Kompensasi Terhadap Produktivitas Kerja". (Studi Pada Perusahaan Layanan Keamanan PT. Garuda Milky Artha, Surabaya).

Wibowo. 2010. Manajemen Kinerja, Edisi 5. Jakarta. Penerbit PT. Rajawali Pers. 